\title{
Creative accounting as one of the global tools for detecting fraud in Europe
}

\author{
Monika Poradova ${ }^{1, *}$ \\ ${ }^{1}$ University of Zilina, Faculty of Operation and Economics of Transport and Communications, \\ Univerzitna 1, 01026 Zilina, Slovakia
}

\begin{abstract}
Research background: The issue of fraud is a real and not an exceptional phenomenon in today's global economies. Fraud arises in businesses at different levels and from different motivations. However, with the development of fraud, methods are also being developed to help detect such fraud. Therefore, the present paper focused on creative accounting as one of the global tools for detecting these scams. The present paper consists of four parts. The first part deals with the issue of creative accounting. The second part describes fraud techniques such as "windows dressing", "off-balancesheet financing" and "earnings management". The third part of the article consists of an analysis of the development of fraud detection in Central and Western Europe. The third part also includes a discussion. The fourth part deals with the conclusions on the issue.

Purpose of the article: describe the issue of creative accounting as one of the global tools for detecting fraud. One of the aims of this paper is also to analyse the development of fraud detection in Central and Western Europe. Methods: In the processing of the present paper, a descriptive method, analysis, mathematical and statistical methods, graphic methods, comparison and synthesis were used.

Findings \& Value added: provide an overview of the conditions for the creation of creative accounting, detection procedures, and the fight against creative accounting. The result of this article is a comprehensive view of the global frauds of Central and Western Europe.
\end{abstract}

Keywords: creative accounting; global economy; fraud; financial statements

JEL Classification: $G 10$; $G 20 ; O 10$

\footnotetext{
* Corresponding author: poradova@,fpedas.uniza.sk
} 


\section{Introduction}

Outputs from the financial statements serve all interest groups of the economic unit inwards and outwards. These statements contain information on the financial performance of companies about its liquidity, profitability, indebtedness and many other important information for its users. (Al-Delawi and Ramo, 2020) The decision-making of each interest group of an economic entity, whether internal or external, is based on information contained in accounting and therefore the principle of providing true and fair images of the company is very important. Only if this information is accurate can users make and make rational economic decisions. The accounting process should be governed by objective and consistent rules to produce accurate and true financial statements. (Dobson-Lohman, 2020)

Improving the results achieved through manipulation in accounting and other similar activities related to accounting can be called creative accounting. In the 1980s, the concept of creative accounting was an unknown concept. With the gradual bankruptcy of larger companies, this concept began to become known to the general public. One of the first publications on creative accounting was a book by the Palestinian writer Kamal Nasser, who published it in 1993. In the book, he described in detail the motives leading to this activity and practice. This is a very important topic that is causing great damage to the economy not only in the world but also in Slovakia. Many people probably know what creative accounting is all about, but on the other hand, they don't know exactly how it works. The term "creative accounting" itself can be defined in several ways. One definition is that it is the process by which accountants use their knowledge of accounting policies to manipulate the accounting data of a particular entity. (Mutuc et al., 2019) Another definition is that creative accounting generally involves the preparation of financial statements with the intention of misleading the final recipients of these statements - referred to as fraudulent fraud. (Saleh et al., 2021) The concept of creative accounting is the intentional distortion of the achieved results of an economic unit by means of gaps, which help to draw the financial statements on one's own picture. (Savova, 2021) As mentioned above, there are a large number of different definitions of creative accounting, but it combines their main feature - the distortion of accounting data so that they are in favour of their engineers. On the contrary, there is as yet no clear agreement on whether creative accounting methods need to be only within "gaps in accounting rules" or can exceed these limits. (Ginevicius et al., 2021)

Creative accounting forms the boundary between the alternative approaches allowed by legislation and fraudulent misrepresentation. It is not uncommon for financial statements to sometimes contain errors and omissions. (Sanhueza and Parada, 2017) For example, to report a higher accounting profit before tax than it actually is, to reduce the tax liability for the company, etc. These are practices that obscure the facts.

Elements of creative accounting are originality, individuality, unconventionality, uniqueness, originality, peculiarity, individuality, risk, courage, etc. When assessing whether or not it is creative accounting, it is important to recognize whether it is an intentional misrepresentation or not. This case is classified as an economic crime. Fraud usually begins with creative accounting, where the effort is a weaker year. As a temporary solution, the company will use some accounting tactics to cover this downturn. If the required results are not achieved in the coming years, creative accounting will continue to be used. (Ejdys et al. 2019)

The first category of reasons for improvement or manipulation of achieved results are personal motivations of managers or executives of the company. Factors of personal motivation are those from which a direct profile for the person concerned follows. This means that they will see it in the form of increased income, better feeling, or more security. In some cases, managers may have financial problems or just greed. Several of the described motivations are confirmed from practice. (Milanov, 2020) 
The first and probably the most common factor that leads to the implementation of creative accounting is that most business managers have a combined salary, which consists of a fixed and a variable component. It is the variable component of wages that depends on the results of companies. Based on this factor, the motivation is, therefore, to report the highest possible sales and thus achieve a wage increase. The bonus increase factor is very similar to the previous one. The bonus can only be paid out after certain results have been agreed upon. (Remenaric et al., 2018) Because of this, there is a high motivation to use creative accounting to achieve such a result. Another very important category in motivating the use of creative accounting is market expectations. Market expectations are one of the other factors for which creative accounting or fraud is on the rise. Businesses publish financial reports about their status. (Kral et al. 2019) Based on this information, predictions are made as to what the numbers might look like in the next year or quarter. The last factor that plays an important role in motivating the use of creative accounting is the legality of this procedure. Since creative accounting is not covered by legislation, this means that it is not directly prohibited.

\section{Methods}

Within creative accounting techniques, we use the definition of creative accounting. Basically, there are three basic techniques that we can find and use.

The first technique is "windows dressing". This technique is less demanding and can be used by less skilled people to improve the position of the company. Especially in terms of profitability. Bigger profit - lower loss, lower profit - higher loss. The second technique is a technique "off - balance sheet financing". However, techniques in this category are much more demanding on the knowledge and expertise of the person performing them. In practice, they are often difficult to detect even by experienced people. The last third technique that requires profit manipulation is called "earnings management". In all three techniques, these are procedures where the manipulation of numerical items in the company's accounting is required. For example, these techniques can result in higher profits in financial statements. (Valaskova et. al. 2021) The company can use these methods to conceal the impending financial risk. It may be a risk of insolvency, to report acceptable values of basic financial indicators. Also, maintain business relationships with business partners or avoid closer scrutiny of the company's supervisory bodies.

\subsection{Windows dressing}

As indicated above, windows dressing consists of techniques that adjust reports to the form their authors want them to have. As a rule, this is about achieving the desired economic results. Transactions are intentionally selected so that the resulting picture does not provide an honest and true picture of the entity's true condition. It is displayed in the form that companies want. This technique is usually aimed at external users of accounting. This technique is also used to manipulate the company's tax base. We can define it as conducting accounting transactions in such a way that the financial statements give a misleading or unrepresentative picture of the company's financial position. (Hung et al., 2020) We can assign the following fraud techniques to this technique. First, we can classify the intentional classification of current assets and liabilities as debt and vice versa. In particular, this procedure will improve liquidity. Intentional replacement of repairs and appreciation of fixed assets and vice versa. Assets without economic benefits can also be included in the techniques used in fraud. Furthermore, repurchases of assets, intentional non-compliance with the precautionary principle, manipulation of the entry price, distortion of income and last but not least, borrowings. 


\subsection{Off - balance sheet financing}

As mentioned above, off-balance sheet financing techniques are much more advanced and challenging recognition techniques. It is the financing or refinancing of business activities, the reflection of which in the company's balance sheet may not appear even in compliance with legal requirements and existing accounting principles. It is common knowledge that a certain level of indebtedness is not only necessary for a company because self-financing is not always possible, but external sources of financing are usually cheaper than internal sources. (Segura and Zeng, 2020) The point is to find a method of financing that does not appear as a liability in the balance sheet, despite the fact that it will cause the company to have funds available from external sources. Such practices include the exchange of financial and operating leases. Accounting for the sale of receivables or factoring depending on their risk arising from non-disclosure of receivables. Guaranteed loans treated as sales and, last but not least, reporting liabilities (debts).

\subsection{Earnings management}

You are free to use colour illustrations for the online version of the proceedings but any print version will be printed in black and white unless special arrangements have been made with the conference organiser. Please check whether or not this is the case. If the print version will be black and white only, you should check your figure captions carefully and remove any reference to colour in the illustration and text. In addition, some colour figures will degrade or suffer loss of information when converted to black and white, and this should be taken into account when preparing them. (Vagner et al. 2021)

The aim of this paper is to analyse the global frauds of Central and Western Europe. More than 5,000 respondents in 99 territories participated in the survey. The first part of the survey will focus on the analysis of potential internal perpetrators of fraud in Central and Western Europe. Subsequently, we will compare Central and Western Europe with some regions of the world in the number of detected frauds. We will compare the data with the regions of the USA and Canada, Southern Asia and Asia-Pacific. The next part of the survey will focus on the types of companies in Central and Western Europe that have fallen victim to fraud in percentage terms. We then analyse the main categories of Central and Western European fraud and the average length of fraud detection in Central and Western Europe. The survey was conducted in the period from 2009 to 2020. The result of this article is a comprehensive view of the global fraud in Central and Western Europe.

\section{Results and Discussion}

The results of the survey show that up to $47 \%$ of the companies surveyed have been fraudulent in the last 24 months. Almost half of the companies surveyed committed at least one fraud. First, we analysed the most common offenders. Therefore, the survey focused on a number of questions focusing on the details of the work of fraudsters. These were fundamental demographic issues, previous abuse of power and behavioral warnings. This information has been compiled to help companies better understand and identify the risks of fraud in their own workforce. From a general point of view, we have divided them into external and internal. External fraudsters accounted for about $36 \%$. Internal $41 \%$ and then agreements between internal and external were approximately $23 \%$. However, when it comes to manipulating financial statements, the most common perpetrators are internal. Internal perpetrators of fraud include senior management, middle management and junior management / operational staff. Figure 1 below shows the percentage of internal fraudsters. 


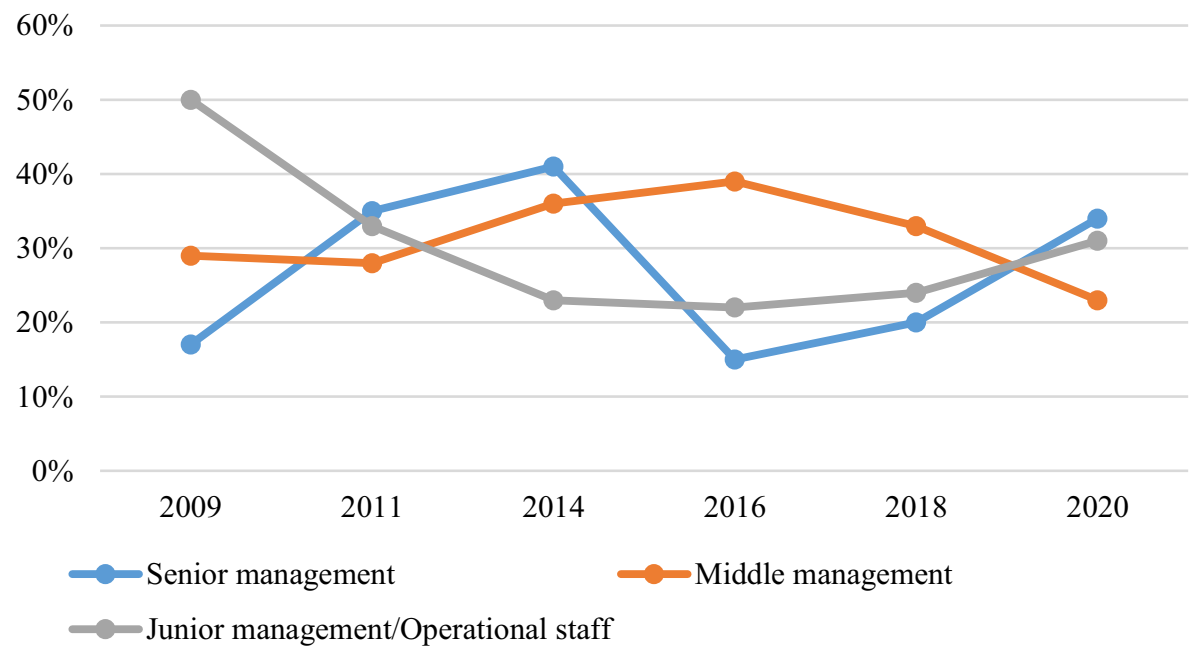

Figure 1. Percentage of internal fraudsters in Central and Western Europe.

Source: Own processing according to Report to the Nation's (2020)

We can see from the picture that in 2009 senior management committed an average of $17 \%$ of frauds. Gradually, fraud within senior management increased. Between 2011 and 2014 , fraud ranged from around $35 \%$ to $41 \%$. In 2020 , an average of $34 \%$ of frauds was committed. Middle management carried out an average of $29 \%$ of frauds in 2009 . Subsequently, between 2014 and 2016, the share of frauds within middle management increased. It ranged from $39 \%$ to $33 \%$. Subsequently, in 2020 , it fell to $23 \%$ compared to previous years. at the level of Junior management / Operational staff, it performed up to about $50 \%$ in 2009 fraud. In the following years 2014 to 2018, the percentage of performed fraud decreased to approximately $20 \%$. However, in 2020, again within this level, fraud increased to $31 \%$.

Figure 2 below shows the percentage of the world's regions compared to the European Union by the number of fraud cases.

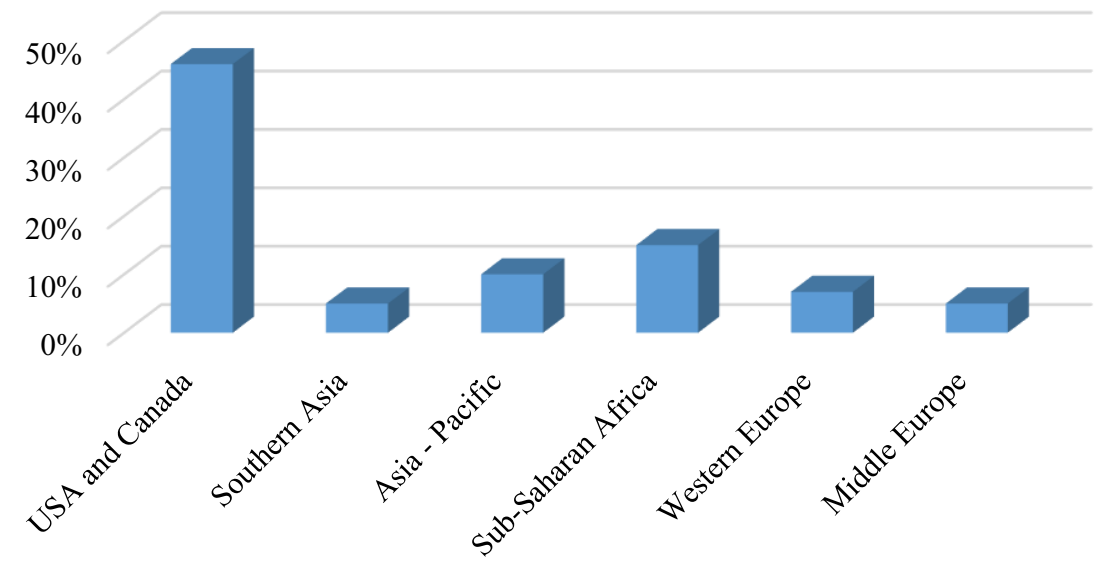

Figure 2. Percentage of regions by the number of detected frauds.

Source: own processing according to Report to the Nation's (2020) 
The largest proportion of cases was recorded in the United States, with a total of 886. Subsequently, it is Sub-Saharan Africa. This part of Africa is known for high levels of conflict and corruption. 295 cases were registered. They are followed by the Asia-Pacific region and Western Europe. Middle Europe and Southern Asia are at a very similar level. Approximately $5 \%$ of frauds were recorded.

The following Figure 3 shows the percentage of types of businesses that have been victims of fraud. $44 \%$ of the businesses that fell victim were mainly private companies. $26 \%$ were public companies.

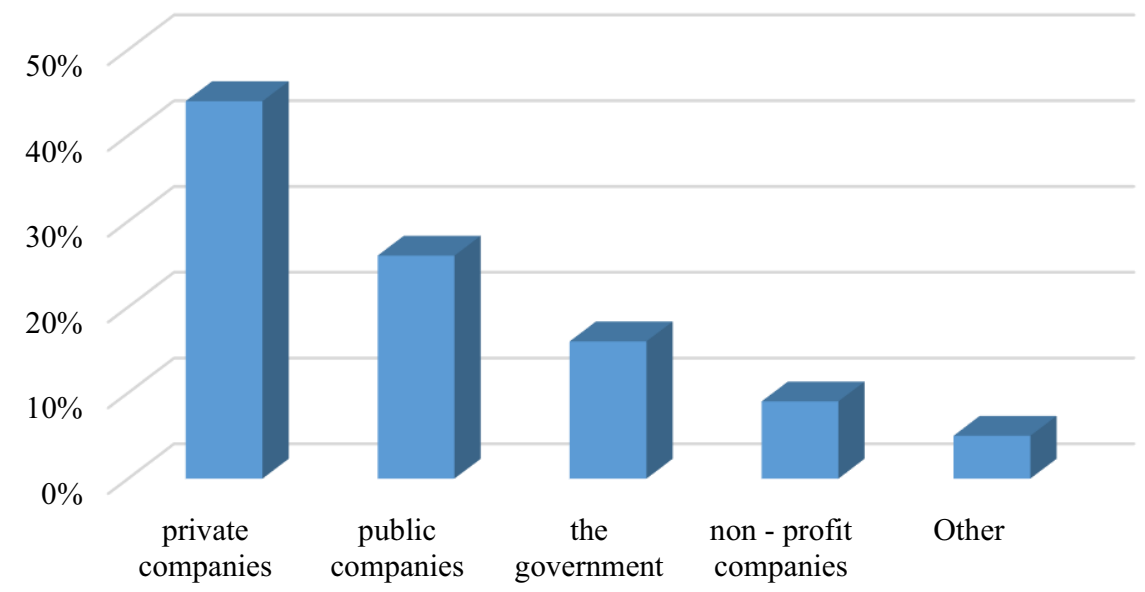

Figure 3. Types of Central and Western European companies that have fallen victim to fraud in percentage terms.

Source: own processing according to Report to the Nation's (2020)

Each private and public organization suffered an average loss of $129755 €$. Non-profit organizations reported only $9 \%$ of fraud cases and suffered the lowest loss of $64877 €$. However, many non-profit organizations initially have limited financial resources, so the loss of this amount can be particularly liquidating for these entities. Public entities at the national level recorded the third-largest number of frauds, around 16\%. They recorded an average loss of $86503 €$. The size of the companies was given on the basis of the number of employees. Small businesses with less than 100 employees had the highest loss of $129654 €$. Large companies with more than 10000 employees had an average loss of $121105 €$.

Another partial result of the present paper is the identification of the main categories of Central and Western European fraud, which are shown in Figure 4. 


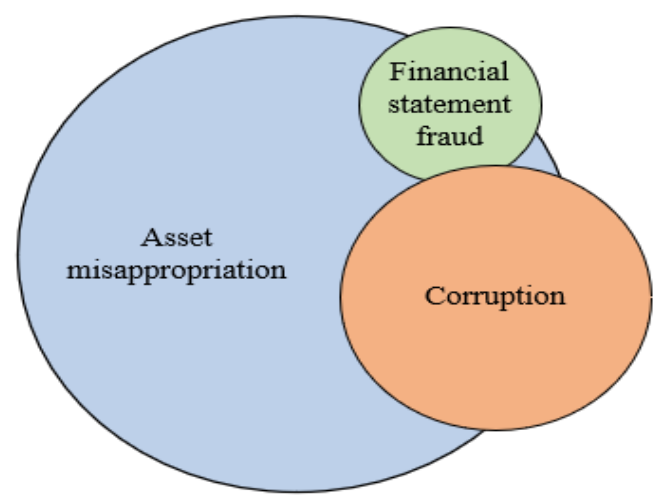

Asset misappropriation only

Asset misappropriation and corruption

Asset misappropriation and corruption

Corruption, asset misappropriation,

and financial statement fraud

Asset misappropriation and financial

statement fraud

Financial statement fraud only

$3 \%$

Corruption and financial statement fraud

Figure 4. The main categories of fraud in Central and Western Europe.

Source: own processing according to Report to the Nation's (2020)

There are three main categories of fraud. Asset misappropriation, which represents up to $87 \%$, consists in the theft or non-utilization of the employer's resources. However, this category tends to cause the lowest loss on average $86503 €$ per case. Conversely, financial statement fraud systems in which the offender intentionally causes material misstatement or omissions in an enterprise's financial statements. These frauds average only $11 \%$, but are the most costly category of fraud. They tend to cause the highest loss on average $825242 €$ per case. The third category is corruption (43\%), which includes, for example, bribery, conflicts of interest, etc. In terms of loss, it also ranks second, which is on average $173007 €$ per case.

It is not possible to prevent all fraud, so rapid detection of fraud is essential to protect the company from possible damage. Figure 5 shows the average length of fraud detection. 


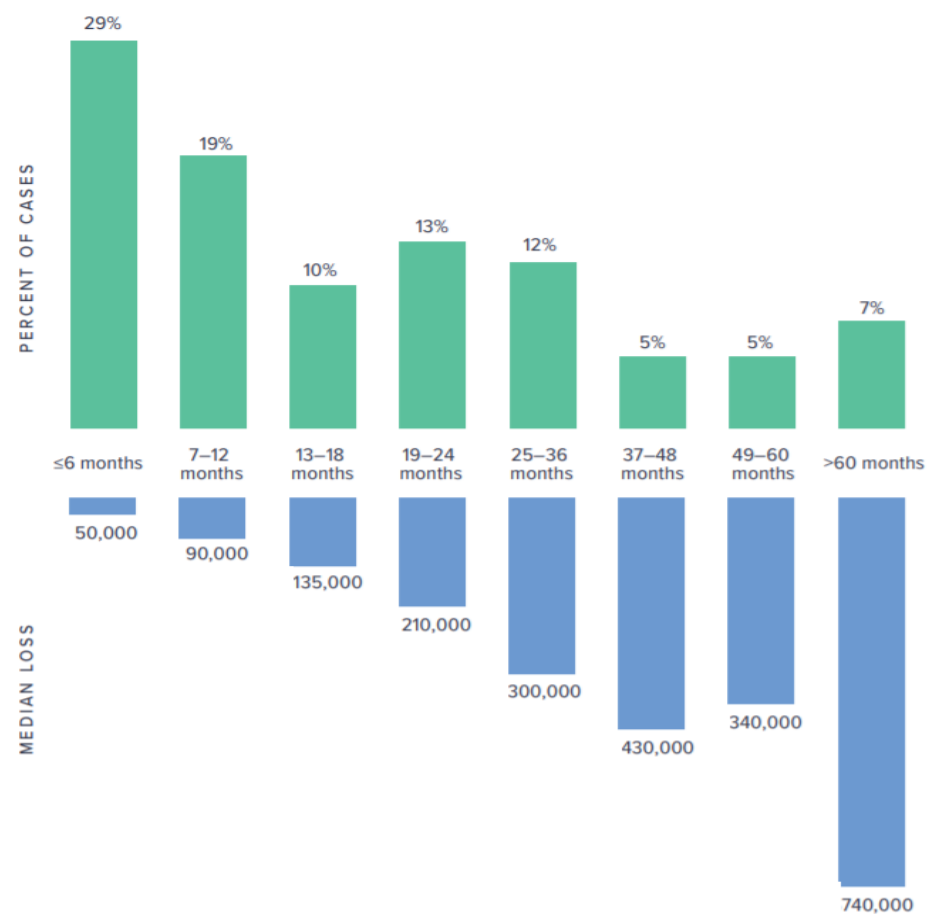

Figure 5. Average length of fraud detection in Central and Western Europe.

Source: own processing according to Report to the Nation's (2020)

Research shows that the median duration of fraud is 14 months. In addition, the later the fraud is detected, the greater the financial loss. As we can see from the picture, if the company detects fraud within 6 months, then the financial loss is on average $50000 €$ per fraud. Subsequently, if it takes the company between 37 and 48 months to detect fraud, the financial loss can increase up to $430000 €$ per fraud. And consequently, if the detection of fraud takes more than 60 months, then the loss can increase up to $740000 €$ per fraud.

Understanding the methods that perpetrators use to conceal their fraud can help companies more effectively detect and prevent similar fraud in the future. The most common methods of concealment of fraud can be divided into four categories. The first category is the creation of false physical documents. The second category is the modification/correction of created physical documents. The third category is the modification/correction of electronic documents and files. The fourth category is the creation of fake electronic documents and files. From this point of view, it is important to detect classified fraud.

The types of fraud as well as the ways in which it is carried out remain consistent. At the highest level, there are three main categories of fraud. These include misappropriation of property, corruption and fraud in financial statements. (Renu and Sharma, 2020) The basis for effective fraud detection is knowledge of the most common methods by which fraud occurs. (Ababneh et al., 2019) More than $40 \%$ of cases were detected using tips, which is almost three times more cases than the method of the most common detection of fraud internal audit. An internal audit revealed only $15 \%$ of cases. $44 \%$ of the companies that fell victim to fraud were private companies. These were mainly companies with up to 100 employees. Independent external audits of companies' financial statements are the most common audits. The financial statements were audited by an external auditor in $83 \%$ of companies. Although the audit is classified as an anti-fraud control, it is important to note that this mechanism is not primarily intended to detect or prevent all fraud. The most common 
perpetrators of fraud in the survey showed that employees (41\%) and men (70\%) acted. The Slovak Republic is included in the Central Europe region, where the most common method of fraud is corruption with a share of $61 \%$. In Slovakia, 3 cases of fraud were recorded out of a total of 95 . The countries with the highest number of cases were Serbia, Romania and Turkey, which had more than 10 cases of fraud.

\section{Conclusion}

Accounting is a method of recording the economic activity of an entity through accounting entries. For the accounting of individual accounting cases, accounting documents are very important, which serve as a basis for accounting. Accounting provides important information for internal and external users. Based on this information, the company's future steps are decided. If this information is distorted, we can assume that it will cause problems in the future. Through accounting, companies are able to manipulate the economic result on which the overall tax liability of the company depends. It is in this situation that the company's owners or managers are motivated to fictitiously improve the company's results, which can only be done through accounting.

The aim of the presented paper was the research and analysis of creative accounting, clarification of creative accounting techniques. Subsequent analysis and interpretation of the results of the global fraud survey, mainly in Central and Western Europe. Of the data obtained from the survey respondents, up to $47 \%$ have experienced fraud in the last 24 months. Corruption can be described as the most serious fraud in almost all regions of the world. The least serious fraud in the survey resulted in fraud with financial statements, which accounted for $11 \%$. However, this fraud brings with it the highest losses. The survey showed that the loss could increase to $825242 €$ per fraud case.

The issue of accounting fraud is therefore still very topical and interesting. Rules and laws are subject to constant change. Methods of fraud are also changing, stimulating the creativity of their creators. For a more optimistic perspective, it should be emphasized that with the development of fraud, methods are also being developed to help detect such fraud.

\section{Acknowledgements}

The paper is an output of the science project VEGA 1/0210/19 Research of innovative attributes of quantitative and qualitative fundaments of the opportunistic earnings modelling which authors gratefully acknowledge.

\section{References}

1. Ababneh, T. A. M., \& Aga, M. (2019). The Impact of Sustainable Financial Data Governance, Political Connections, and Creative Accounting Practices on Organizational Outcomes. Sustainability, 11(20).

2. Al-Delawi, A. S., \& Ramo, W. M. (2020). The impact of accounting information system on performance management. Polish Journal of Management Studies, 21(2), 36-48.

3. Dobson-Lohman, E. (2020). Artificial Intelligence-based Decision-Making Algorithms, Internet of Things Smart Devices, and Real-Time Process Monitoring in Sustainable Industry 4.0, Economics, Management, and Financial Markets, 15(2), 30-36.

4. Bruce D. (2020). Report to the Nation's. Austin. 
5. Ejdys, J., Ginevicius, R., Rozsa, Z., \& Janoskova, K. (2019). The role of perceived risk and security level in building trust in E-government solutions. $E+M$ Ekonomie a Management, 22(3), 220-235.

6. Ginevicius, R., Kliestik, T., Stasiukynas, A., \& Suhajda, K. (2021). The Impact of National Economic Development on the Shadow Economy. Journal of Competitiveness, 12(4), 39-55.

7. Hung, P. H., Lien, D., \& Kuo, M. S. (2020). Window dressing in equity mutual funds. Quarterly Review of Economics and Finance, 78, 338-354.

8. Kral, P., Valjaskova, V., \& Janoskova, K. (2019). Quantitative approach to project portfolio management: proposal for Slovak companies. Oeconomia Copernicana, 10(4), 797-814.

9. Milanov, A. (2020). Risk measurement and evaluation in RFI and RFP processes at the Bulgarian mobile telecommunication operators. Ekonomicko-manazerske spektrum, 14(2), 24-35.

10. Mutuc, E. B., Lee, J. S., \& Tsai, F. S. (2019). Doing Good with Creative Accounting? Linking Corporate Social Responsibility to Earnings Management in Market Economy, Country and Business Sector Contexts. Sustainability, 11(17).

11. Remenaric, B., Kenfelja, I., \& Mijoc, I. (2018). Creative accounting - motives, techniques and possibilities of prevention. Ekonomski Vjesnik, 31(1), 193-199.

12. Renu, \& Sharma, N. (2020). Creative accounting: an interaction of hr and accounting. Jims 8m-the journal of Indian management \& strategy, 25(1), 19-27.

13. Saleh, M. M. A., Jawabreh, O., \& Abu-Eker, E. F. M. (2021). Factors of applying creative accounting and its impact on the quality of financial statements in Jordanian hotels, sustainable practices. Journal of Sustainable Finance \& Investment, 54(4).

14. Sanhueza, R. H., \& Parada, F. M. (2017). A Perspective on the Creative Accounting Phenomenon form IFRS and IPSAS. Revista Perspectiva Empresarial, 4(1), 85-94.

15. Savova, K. (2021). Variable application of accounting standards - current aspects. Ekonomicko-manazerske spektrum, 15(1), 111-122.

16. Segura, A., \& Zeng, J. (2020). Off-balance sheet funding, voluntary support and investment efficiency. Journal of Financial Economics, 137(1), 90-107.

17. Vagner, L., Valaskova, K., Durana, P., \& Lazaroiu, G. (2021). Earnings management: A bibliometric analysis. Economics and Sociology, 14(1), 249-262.

18. Valaskova, K., Adamko, P., Frajtova-Michalikova, K., \& Macek, J. (2021). Quo Vadis earnings management? Analysis of manipulation determinants in Central European environment. Oeconomia Copernicana, 12(3). 